\title{
The development of urban agglomeration in a pandemic
}

\author{
Svetlana Korotkova ${ }^{1 *}$ [0000-0001-8303-5580], Anastasiya Dobrolyubova ${ }^{2}$, and Galina Filyushina ${ }^{1}$ \\ ${ }^{1}$ Kazan State University of Architecture and Engineering, 420043, Zelenaya st., Kazan, Russia \\ ${ }^{2}$ Architectural bureau «Pyat», 420071, Kazan, Russia
}

\begin{abstract}
The features of the modern development of urban agglomerations should be considered from the standpoint of the changed conditions of the socio-ecological space. They are associated with the situation of a pandemic, which is especially aggravated in large cities. Since Kazan is a developing city, the possibilities of creating new conditions on the territory of expansion were considered. Two aspects of design are considered, which are associated with the study of the clinical manifestations of viral diseases and the formation of resilience in the organization of the environment for elderly people. The study highlights the main features of design approaches for centers studying human immunology and residential clusters that take into account the characteristics of the elderly. In the context of the territory, design principles were proposed, considered as infrastructure principles and residential cluster principles. The infrastructure associated with human learning is expressed in the following: isolation, planning cyclicality, polyfunctionality, accessibility for the elderly. Residential development is based on: spatial identity, human scale of the environment, continuity of communications, inclusion in the natural environment. Thus, it seems possible to work out a unique solution in terms of sustainable development of previously abandoned territories. Attentive attitude to landscape components is on a par with a humanistic attitude towards the most vulnerable groups of the population.
\end{abstract}

Keywords: humane design, development project, centers of immunology, housing for the elderly, urban agglomeration.

\section{Introduction}

The society, during development, faced problems, that can't be solved in the near future. A large number of people today live in concentrated way, in large cities and megalopolises. Territorial resources of cities are not adapted to the changed conditions of safe living. The people of senior age groups are at risk of developing serious complications and death as a result of COVID-19 coronavirus infection. The UN materials declare as an inclusive, fair and taking into account the age society, and support the principle of sustainable

\footnotetext{
${ }^{*}$ Corresponding author: svetlkor@yandex.ru
} 
development for the period up to 2030 , which says «no one should be forgotten» ${ }^{1}$. This is an incentive for research not only in the medical sphere, but also in the sphere of urban architecture.

Renovation is the most frequent approach to enhancing the architectural and urban attractiveness of the city. Not all renovation of territories leads to sustainable development. That way, environmental renovation should be a priority method of updating the urban environment. The concept of sustainability is considered in many modern studies that are associated with landscape urbanism. It considers the artificial object as a continuation of the natural landscape, so these ideas are easier to implement within one building or complex than in the town-planning development of significant territories.

The success of the sustainable development of the territory is considered possible in the area where the development just begins to take place. The city of Kazan is actively developing in the direction of the North-West, including the area of Poroshkovaya Sloboda. These territories require solutions to issues related to the regeneration of sites, providing the balance between the economy, the social sphere and the environment. In order to clarify the potential of the territory, an integrated analysis of the prerequisites for its development was carried out. The prerequisites of territories development were analyzed to understand the possibilities. [1].

The purpose of this study was to identify the most acceptable forms of the development of agglomeration in the conditions of the pandemic crisis in the structure of a large city, the example of which is Kazan. At the same time, many researchers suggest that the uniformity of the settlement of various social segments of the population is a favorable factor in the urbanization of the territories. For this, such living models are developing as a «family house». Residential building, which provides for differences in the lifestyle of the elderly and the younger generation, receives priority not only from social positions, but also in economic calculations [2].

The way in which the study was conducted represents assessment of the acceptable organization forms of infrastructure for the elderly in the conditions of a pandemic. Two directions of the formation of settlement were considered: a residential cluster, taking into account the residence of the elderly and a research cluster, studying the medical and humanitarian aspects of sustainable development. The study used materials obtained by assessing the availability of public spaces. The principles of universal design were the basis for the design of the environment, regardless of whether a person has a disability or not [3].

\section{Materials and methods}

\subsection{Territorial development of agglomeration}

Former industrial territories of cities are the resource that has the relationship between different elements of natural and anthropogenic landscape. The territory of the planned development was taken in accordance with the draft General Plan of the city of Kazan. The situation in the center of the Kirovsky district determined the distance from the densely populated quarters and the main points of growth. It is surrounded with forest natural territories and transport infrastructure zones. Conjugated with a plot and located on a slight distance, residential housing incudes individual residential buildings with household

1 Secretary-General's Policy Brief: The Impact of COVID-19 on Older Persons, http://www.un.org/development/desa/ageing/wp-content/uploads/sites/24/2020/05/COVID-Olderpersons.pdf 
sections, as well as apartment buildings of small and medium height (up to 5 floors). The advantage of the studied area was the presence of extensive spaces of natural landscapes with coniferous and wide forests. There are specially protected natural territories of regional importance: the city forest park «Lebyazhye» and the Volga River. Because of the favorable environmental situation and the presence of large arrays of landscaped areas, this area has the potential to form a new type of urban environment creating a positive image of the Kirovsky district.

In order to identify and systematize the factors determining the development of the site, a SWOT analysis was conducted. Among the strengths for development we should mention that it is possible not only to create an optimal planning structure of residential building, but also to maintain existing forest plantations. The weaknesses of the site are the insecurity of the socio-guaranteed minimum of public service facilities and the low transport accessibility of this urban direction. A decrease in the volume of housing entry in the city is noted, which indirectly indicates post-crisis problems. According to the environmental situation, various indicators in the areas of the city (emissions into atmospheric air, the pollution of soil cover, etc.) characterize the negative state of Kirovsky, Moscowsky and Aviastroitelny districts. This is associated with the location of a number of large industrial enterprises.

The data of sociological surveys were used, which were aimed at assessing the demand for housing, the type of employment of respondents, gender and socio-demographic characteristics of consumers. Accounting for the location of the territory in the distance from the central parts of the city the survey was aimed at identifying positive factors. The main factors that can make remote accommodation are more attractive - good social infrastructure (61\%), good transport connectivity (49\%), good ecology (46\%), close location of work and home (42\%), as well as lower cost of housing (38\%). The identification of factors capable of making remote housing more attractive has been determined in this study. The main requests were related to the possibility of pedestrian accessibility of social and recreational infrastructure facilities (80-100\%), household services (50-68\%), as well as the possibility of choosing a type of transport.

\subsection{Sustainable social development}

The study used methods to systematize and classify the decisive features and qualities. Such features were the possibility and effectiveness of the implementation of the basic functions of life in relation to the contingent of senior people [4]. Improving the quality of life of people of retirement age allows meeting the requirements rapidly changing in a pandemic, social medium. The development of the medium occurs when old people are not only involved in social life, but are an integral part of the adaptive space. The architectural environment of residential buildings affects the emotional world, the consciousness and behavior of the older generation. The most humane effects are provided by spaces organized according to the principles of sustainable development of the territory [5]. Based on such principles, the typology of houses for the elderly was analyzed. The most progressive form of residence was the houses of municipal and inter-flow type, based on the principles of mutual assistance and communication within the family [6].

The study of world experience in building environmental areas in various European countries similar in the climatic conditions and other physico-geographical characteristics with Kazan, allowed us to identify three morphotype of eco-regions, differing in the nature of integration into the environment [7]. This is a diffuse integrated building; urban village (cluster building); The city «under the canopy of the forest».

However, our study revealed the need to determine the new socio-spatial framework of an environmentally friendly area for old people [8]. This was affected by such a factor as a 
pandemic crisis. There was a need to form a research cluster in contact with residential building.

The main town-planning aspects that were allocated in connection with the placement of the Multifunction Research Center:

- The complex of the scientific cluster should be located in the distance from housing;

- Transport and pedestrian ways: railway or route;

- The proximity of natural elements: relief, reservoir, etc.;

- Development of social infrastructure [9].

\section{Results}

The types of services for the care and support of older people are different today, but these services are limited and inaccessible to all in many places. Family members are the only services available for them to care and support. In this regard, it is proposed to apply the principle of approximate service $[10,11]$. Its application is meant in a research cluster, where the immune system of a person is being studied. The main function of the immunological center is studying the lifestyle of a person and his reaction to external factors [12]. As a result of the analysis of such a resource as an urban environment, general design techniques have been formed, which are able to create competitiveness in this area of agglomeration:

- original design concepts of general use of public places;

- preschool and secondary institutions with a unique education system and developed infrastructure [13];

- use of environmentally friendly materials and energy-saving technologies;

- the concept of «country life within the city» - the formation of autonomous communal infrastructure, own educational and commercial facilities;

- improvement of own recreational spaces (parks, boulevards) [14].

The classification features of research centers for the study of the immune system are formulated, project types invariants are given. (Fig. 1).

Research laboratories «Environment for scientists».

This type of centers involves social interaction of scientists in the process of studying problems. Features of the functional zoning of the center are large sites for the interaction of a large number of people, separate laboratories with isolated premises, the study part for lectures and performances [15]. The main feature of the «Scientists' Environment» is complete satisfaction with all requirements for residence and active scientific activities. It is a place of residence, an active recreation area in nature, a library, recreational areas for recreation in non-school time, large rooms for meetings, presentation zones.

Laboratories for the study of genetics.

This type of research complex involves scientists from all over the world. The buildings have a complex configuration. The basis of the functional structure is the various types of laboratories. There are experimental chambers for studying the topic on samples. There is a need for freezers, light-proof storage rooms and warehouses, for the storage of genetic material.

Village centers.

For the design of the center - «village», a remote place is allocated, but it has a transport connection with major highways. The science campus combines office buildings, a wellness center, and a group of research laboratories. Entrance areas include a park and a representative square. Exhibition spaces are typical for the study and presentation of complex biochemical processes. Large exhibition halls, conference halls, demonstration laboratories are aimed at presenting modern medical technologies to the world medical 
community. In the central part of the office there are administrative services, common meeting rooms and open work areas. Individual closed offices are located along the facades.

Research centers combined with industrial or agricultural centers.

For the location and geology of the object, a flat area is allocated. A clear division is seen in the formation of the building shape. The internal volume is divided in half; laboratories are located in one half and administrative and classroom facilities are located on the other. The division line is supplemented by internal public areas that have their own functional programs.

\begin{tabular}{|c|c|c|c|c|c|}
\hline $\begin{array}{l}\text { Experie } \\
\text { nce }\end{array}$ & $\begin{array}{l}\text { BioLegend Campus } \\
\text { Delavie }\end{array}$ & 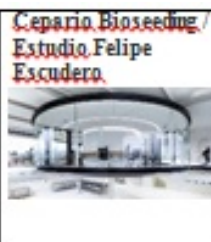 & $\begin{array}{l}\text { Bioprocess Innovation } \\
\text { Center / Clark Nersen } \\
\end{array}$ & $\begin{array}{l}\text { National Laboratory } \\
\text { of Genomics / TEN } \\
\text { Arquitectes. }\end{array}$ & $\begin{array}{l}\text { comamon } \\
\text { characteristic }\end{array}$ \\
\hline $\begin{array}{l}\text { Charact } \\
\text { eristics } \\
\text { (the } \\
\text { nature } \\
\text { of the } \\
\text { links) }\end{array}$ & & & & D & $\begin{array}{l}\text { - horizontal } \\
\text { bridges; } \\
\text { - ring connections; } \\
\text { - pedestrian } \\
\text { connections on the } \\
\text { territory; } \\
\text { - tower-sccent }\end{array}$ \\
\hline Function & & & & & $\begin{array}{l}\text { - scientific } \\
\text { building; } \\
\text { - insulated housing; } \\
\text { - educational } \\
\text { building; } \\
\text { - recreational areas; } \\
\text { - commercial areas }\end{array}$ \\
\hline $\begin{array}{l}\text { Planning } \\
\text { structure }\end{array}$ & & & & & $\begin{array}{l}\text { - central atrium; } \\
\text { - isolated } \\
\text { laboratory cells; } \\
\text { - multi-level } \\
\text { galleries and halls; } \\
\text { - courtyards; } \\
\text { - enfilade service } \\
\text { areas; } \\
\text { - accentusted } \\
\text { entrance groups; } \\
\text { - visual links to the } \\
\text { territory }\end{array}$ \\
\hline $\begin{array}{l}\text { The } \\
\text { nature } \\
\text { of the } \\
\text { interior }\end{array}$ & & & $\begin{array}{c}2 \Omega \\
2 \\
2\end{array}$ & 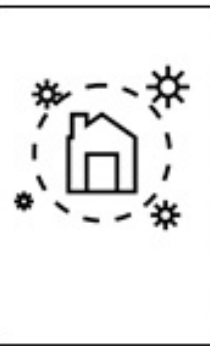 & $\begin{array}{l}\text { natural sun } \\
\text { exposure; } \\
\text { translucant } \\
\text { partitions; } \\
\text { navigation systems } \\
\text { natural elements } \\
\text { inside; } \\
\text { permanent } \\
\text { antimicrobial } \\
\text { costings; } \\
\text { views of outdoor } \\
\text { landscaping }\end{array}$ \\
\hline Eमipmen & 임 & & & ש & $\begin{array}{l}\text { - antimicrobial } \\
\text { surfaces; } \\
\text { - fiberglass for } \\
\text { laboratory } \\
\text { fumiture; } \\
\text { - wooden surfaces } \\
\text { K0, fire protention } \\
\text { impregnations }\end{array}$ \\
\hline
\end{tabular}

Fig. 1. Classification features in the engineering of immune research objects. 
Scientific laboratory-insulator.

This type of design solution consists of three functional spaces - a pantry, a laboratory and a living room. The living room is a place where ideas accumulate. The laboratories are located next to the isolation ward. However, the isolator and laboratory are separated by air pockets and heat and oxygen treatment zones. Most often in this type of design, a closed contour of the room is found. This helps to limit the spread of viruses and makes the presence areas safe for researchers.

Strengthening the social health system is crucial to ensure a higher level of health and well-being for the older generation $[16,17]$. Therefore, the identified techniques in relation to the center for immunology research are considered in connection with the location on the project territory. The balance of two aspects - strengthening the immune system and the required living conditions of the elderly - was considered in a potential territory with a sustainable ecosystem. The characteristic features of sustainable design were also supplemented in the table of classification of living conditions of the elderly (Fig. 2).

\begin{tabular}{|c|c|c|c|c|c|}
\hline Experience & $\begin{array}{l}\text { Future Solund } \\
\text { House of } \\
\text { Generations }\end{array}$ & $\begin{array}{l}\text { Armstrong Place } \\
\text { Senior Housing2 } \\
\text { House-community }\end{array}$ & $\begin{array}{l}\text { La Valentina } \\
\text { Station4 } \\
\text { Social Housing }\end{array}$ & $\begin{array}{l}\text { Квартал } \\
\text { Tassafaronga } \\
\text { Village6 } \\
\text { Social housing, as an } \\
\text { object of } \\
\text { reconstruction }\end{array}$ & General characteristics \\
\hline $\begin{array}{l}\text { Characteris } \\
\text { tics (the } \\
\text { nature of } \\
\text { the links) }\end{array}$ & & & & 亩 $\rightarrow$ 㽞 & $\begin{array}{l}\text { - resource efficiency of } \\
\text { buildings; } \\
\text { - reconstruction of } \\
\text { buildings; } \\
\text { - pedestrian connections } \\
\text { on the ternitory, }\end{array}$ \\
\hline Function & & & & & $\begin{array}{l}\text { - housing; } \\
\text { - trade; } \\
\text { - maintenance; } \\
\text { - rehabilitation; }\end{array}$ \\
\hline $\begin{array}{l}\text { Planning } \\
\text { structure }\end{array}$ & & & & & $\begin{array}{l}\text { - wallkways between } \\
\text { buildings; } \\
\text { - multi-level galleries } \\
\text { and halls; } \\
\text { - internal courtyards; } \\
\text { - total.spaces; } \\
\text { - visual links to the } \\
\text { territory } \\
\text { - noise insulation }\end{array}$ \\
\hline $\begin{array}{l}\text { The nature } \\
\text { of the } \\
\text { interior }\end{array}$ & & (S⿵冂卄一 & 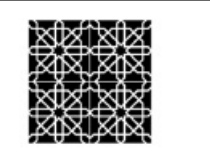 & 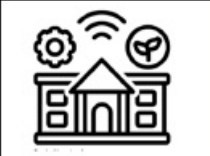 & $\begin{array}{l}\text { - natural sun exposure; } \\
\text { - perforated translucent } \\
\text { partitions; } \\
\text { - national ornaments; } \\
\text { - maximum comfort }\end{array}$ \\
\hline
\end{tabular}

Fig. 2. Classification signs in the design of facilities for the elderly.

Type of residence «house of generations». Several generations of the family live separately, but have common spaces for communication and interaction. One part of the residential area represents apartments for older people who need special care. The other part is apartments for the elderly and apartments for young people. Thus, the variability of public spaces with different degrees of privacy is formed. Public areas acquire a functional addition; for example, a dining room, a common living room, terraces, an operational roof, a courtyard. 
Type of residence «house-community». In this case, the elderly live separately, engaging in collective activities. Sometimes two levels are enough, located in a green area, or near a park. It is characterized by openness to the outside, when a public area passes through at ground level. On the second floor there are atriums. Residential cells are «communities» on each floor. Each community consists of rooms for residents and one employee, a dining room and a kitchen. The trajectory of movement to private rooms from any part of the building is reduced. The system of orientation in space is solved by a special color scheme [18].

Type of residence «social housing». It is affordable housing with resource-saving operation of the building. The main task to be solved was to rehabilitate the disadvantaged area. Increasing the attractiveness of the location of housing was the creation of a popular transfer hub. The complex for single or family residents with an average or lower income is located on a previously empty land plot near the tram station. To preserve the privacy of residents from the street side, the glass is covered with a «barcode» pattern.

«Social housing as an object of reconstruction» is associated with the usual appearance of a city house. This type often forms a buffer space between residential and industrial areas. The use of this approach allows the reuse of existing buildings, which gives the old buildings a new special character.

The criteria are applied by which the features of infrastructure facilities in developing areas of the city are revealed. Thus, a project approach is defined for the development of agglomeration in a pandemic.

\section{Discussion}

The aim of this study was to create favorable living conditions for a vulnerable group of the population. When analyzing the processes of the immune system against the background of the epidemiological situation in the world, the main blow falls on the elderly [19]. One of the methods identified was the organization of a comfortable and accessible environment. Our medical and social studies have shown that the reason for the paramount importance of living in a residential complex is a decrease in the ability to self-care. This speaks to the great importance of medical and social work. More than a third of older people cannot do without constant medical care and social services. The main focus of the research of the Center for the Study of Diseases of the Immune System is the imperfection and unpreparedness of the population for the conditions of a pandemic. This problem is being solved by creating a research platform organized to solve urgent problems. To update the current situation, a review of the research literature was conducted [20,21, 22].

\section{Research limits.}

When organizing the territory and designing the architectural environment, the optimal solution was to combine a social residential complex and a research center to effectively solve the problem. The main idea of the planning development was the creation of a unified structure with a comfortable movement of a group of the population in the healthimproving part of the complex, combined with a scientific center (Fig. 3). This building is intended to provide medical care and restricts their access to laboratory research. The rest of the center is focused on the study of the immune system and a platform for educating students and healthcare professionals. 


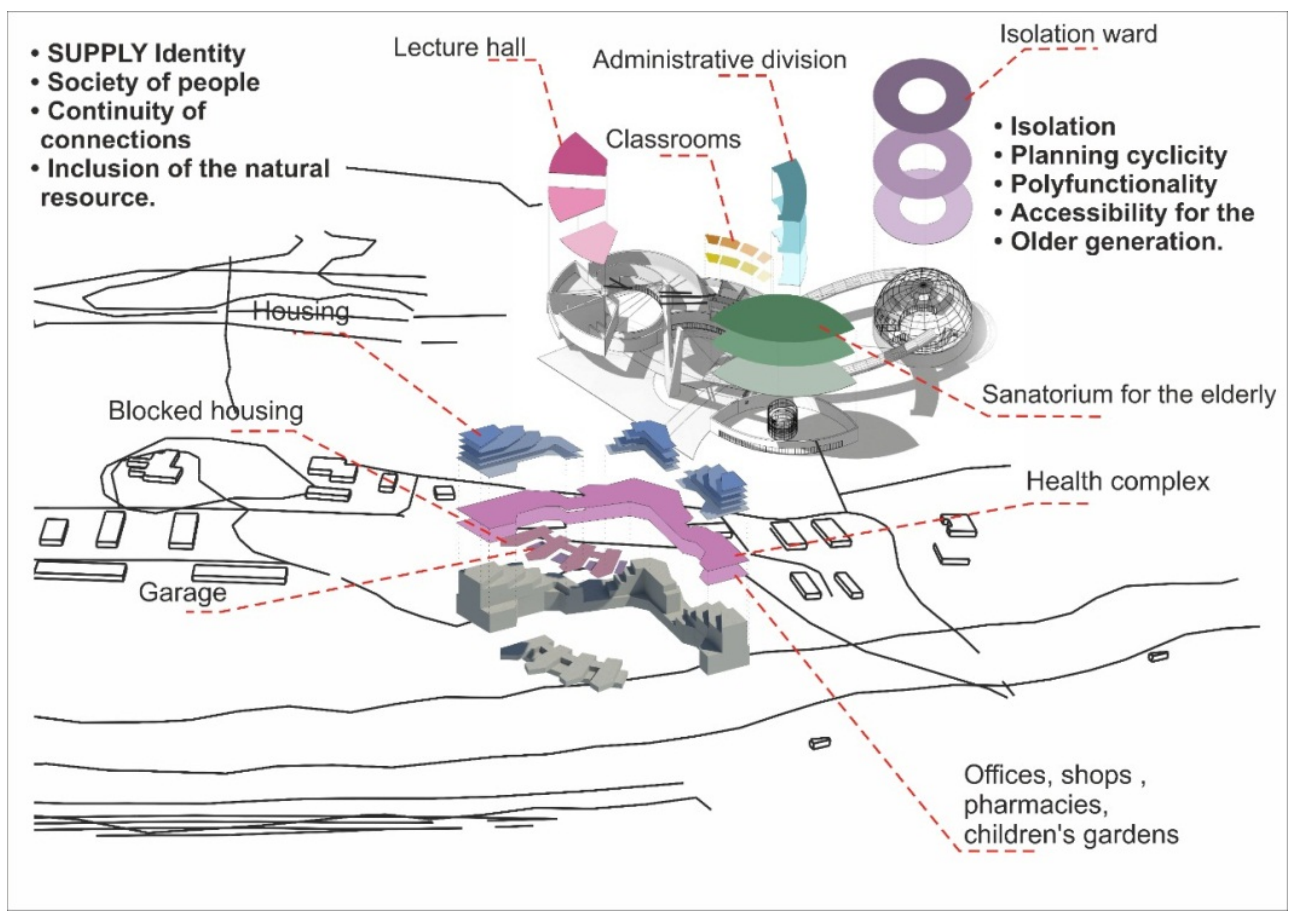

Fig. 3. Design principles for the development of the territory in a pandemic.

\section{Future research.}

This structure can be adapted not only for the elderly, but also for creating conditions for people with limited physiological characteristics, requiring special conditions for a comfortable life. Also, the study of the immune system depends on many factors, such as the influence of ecology on the body. A research center can be designed to study the negative impact of the environment on humans, which also affects immunity and even a genetic trait.

\section{Remarks.}

The complexity of the implementation of this project in a particular region lies in the provision of hard-to-reach equipment and the lack of qualified personnel. The issue of the livelihoods of the elderly does not receive the attention it deserves. It happens due to economic inefficiency. Humanity needs to rethink the lifestyle model. By creating scientific and social projects, we will be prepared for dangerous conditions. The opening of new social complexes for a limited group of the population will ensure a comfortable life and improve the demographic situation.

\section{Conclusion}

Taking into account the basic ecological principles of ecological sustainability, it turned out to be possible to combine some of these typological features of the research objects and the residential cluster. A special influence here was exerted by: a favorable ecological environment, the possibility of creating autonomous «start-up» complexes and the presence of a certain well-established image of the Poroshkovaya Sloboda among the residents of the city.

The types of projects of centers for the study of the human immune system are classified according to the following criteria: the nature of internal connections, functional 
planning structure, interior features and the nature of equipment. Comparative characteristics made it possible to substantiate the design principles. It is necessary to isolate certain elements of the research spaces from the general public service system. The structure of the spaces has a certain cyclical structure, taking into account the safety of contacts during a pandemic. The service infrastructure is diverse and targeted at older people.

The types of living spaces are presented and combined: according to the nature of communication of older people, the completeness of their life, the need for accessibility of external and internal spaces. The design principles used in the residential cluster make it possible to develop a systematic approach to solving the problem of adapting the living environment of an elderly person in connection with the pandemic crisis. Identity as a principle of the formation of a district is expressed not only in the figurative characteristics of the development, but also in the peculiarities of the service system in relation to the elderly. For them, special measures are taken when organizing landscape connections and components, accessibility for receiving medical services or spending leisure time, maintaining a healthy lifestyle. The principle of the human-scale environment is a tool for regulating the types and quality of living space, ways of its development. The principle of continuity of ties is manifested in a combination of spatial accessibility and the demand for such a social resource as a connection between generations. This is manifested in the variety of buildings and maximum integration of buildings into the surrounding natural landscape. Also, the principle of inclusion in the natural environment contributes to the preservation of existing ecological flows - the free movement of animals. According to the last principle, a zone of ecological calm is formed, which is especially important in a pandemic situation.

We can assume a certain combination of urban and "suburban" lifestyle, when special land plots are allocated for individual and collective truck farming and gardening. The presence of such multifunctional content conveys a specific lifestyle in developing areas. Further study of such questions is possible later.

\section{References}

1. G. Biddau, A. Marotta, G. Sanna, Abandoned landscape project design, City, Territory and Architecture, 7, 10 (2020) DOI:10.1186/s40410-020-00118-7

2. F. Zanfi, C. Merlini, V. Giavarini, F. Manfredini, A portrait of Italian «Family houses»: diversified heritage in a redefined territorial and demographic context, City, Territory and Architecture, 7, 20 (2020) DOI:10.1186/s40410-020-00125-8

3. S. Gamache, E. Morales, L. Noreau, I. Dumont, J. Leblond, Measure of environmental accessibility (MEA): development and inter-rater reliability, Journal of Accessibility and Design for All, 8, 1, 217-241 (2018) DOI: 10.17411/jacces.v8i1.141

4. S. Gamache, F. Routhier, W. B. Mortenson, W. C. Miller, K. A. Ginis, Objective evaluation of architectural obstacles encountered in two Canadian urban settings by mobility device users, Journal of Accessibility and Design for All, 10, 1, 98-123 (2021) DOI: 10.17411 jacces.v10i1.186

5. C. Zecca, R. Laing, Reading underused urban spaces: Aberdeen views Sustainable Cities and Society, 56, 102108 (2020) DOI:10.1016/j.scs.2020.102108

6. B. P. Hasiholan, I. H. Susilowati, C. Satrya, The conformity of anthropometric measurements of bathroom and bedroom designs for independent elderly at Panti Sosial Tresna Werdha (PSTW)* Budi Mulia I Jakarta in 2018, Journal of Accessibility and Design for All, 9, 1, 25-40 (2019) DOI: 10.17411/jacces.v9i1.200 
7. E. Iusupova, Z. Aglyamova, S. Korotkova, Creating conceptual model of a multifunctional residential building based on sustainable design methods, Izvestiya KGASU, 2(48), 108-116 (2019)

8. E. B. Enginoz, H. Savli, Examination of accessibility for disabled people at metro stations, Iconarp International Journal of Architecture and Planning, 4, 1, 34-48 (2016), DOI:10.15320/ICONARP.2016120307

9. M. Rzeszotarska-Palka, M. Czalczynska-Podolska, Taming the urban space IOP Conference Series, Materials Science and Engineering, 471(9), 092045 (2019) DOI:10.1088/1757-899X/471/9/092045

10. M. Ghorbanzadeh, K. Kim, M. W. Horner, A comparative analysis of transportationbased accessibility to mental health services, Transportation Research Part D: Transport and Environment, 81, 102278 (2020) DOI:10.1016/j.trd.2020.102278

11. Y. Ham, J. Kim, Participatory sensing and digital twin city: updating virtual city models for enhanced risk-informed decision-making, Journal of Management in Engineering, 6(3), 04020005 (2020) DOI:10.1061/(ASCE)ME.1943-5479.0000748

12. S. Barreiro, C. Miguel, H. Mateus, B. Simone, Displacements and philosophy: a study on movement and space perceptions involving children, Praxis \& Saber, 10, 23, 177197 (2019) DOI:10.19053/22160159.v10.n23.2019.9729

13. T. Moskalenko, S. Korotkova, Methods of forming a correctional and developing environment for children with mental retardation, Izvestiya KGASU, 2(48), 98-107, (2019)

14. I. Kaymaz, D. Oguz, Ozlem Candan Cengiz-Hergul, Factors influencing children's use of urban green spaces, Indoor and Built Environment, 28, 4, 520-532 (2019) DOI:10.1177/1420326X17705943

15. R. M. Harahap, I. Santoso, D. Wahjudi, W. Martokusumo, Study of interiority application in deaf space based lecture space: Case study: the Center of Art, Design and Language in ITB building. Journal of Accessibility and Design for All, 10, 2, 229261 (2020) DOI: 10.17411/jacces.v10i2.245

16. L. Bianco, Universal design: from design philosophy to applied science, Journal of Accessibility and Design for All, 10, 1, 70-97 (2020) DOI: 10.17411/jacces.v10i1.249

17. J. Kim, M. Schwartz, A. Zarzycki, The Wave of Autonomous Mobility: Architecture Facilitating Indoor Autonomous Navigation 34th eCAADe Conference. Complexity and Simplicity (Oulu) vol 1 (Finland: Univ Oulu, Oulu Sch. Architecture) 53-58, (2016)

18. A. Bonenberg, Architectural and Urban Spaces for Creative Thinking. Visual Data and Questionnaire Analysis Methods in Support of Design Process, Advances in Intelligent Systems and Computing, 966, 313-322 (2020) DOI: 10.1007/978-3-030-20151-7_30

19. E. Morales, S. Gamache, G. Edwards, Winter: Public Enemy \#1 for Accessibility Exploring New Solutions, Journal of Accessibility and Design for All, 4, 1, 30-52 (2014), DOI: 10.17411/jacces.v4i1.57

20. E. I. Mosca, J. Herssens, A. Rebecchi, S. Capolongo, Inspiring architects in the application of design for all: knowledge transfer methods and tools, Journal of Accessibility and Design for All, 9, 1, 1-24 (2019) DOI: 10.17411/jacces.v9i1.147

21. S. Shu, H. Ma, The restorative environmental sounds perceived by children, Journal of Environmental Psychology, 60, 72-80 (2018) DOI:10.1016/j.jenvp.2018.10.011

22. R. C. Feitosa, S. J. Wilkinson, Small-scale experiments of seasonal heat stress attenuation through a combination of green roof and green walls, Journal of Cleaner Production, 250, 119443 (2020) DOI:10.1016/j.jclepro.2019.119443 